\title{
Model Pelestarian Benda Cagar Budaya (BCB) Kabupaten Buru
}

\author{
Abdul Rasyid Rumata ${ }^{1^{*}}$, Abdi Wael ${ }^{1}$, Muhammad Sehol ${ }^{2}$ \\ ${ }^{1}$ Fakultas Agama Islam, Universitas Iqra Buru, Indonesia \\ ${ }^{2}$ Fakultas Keguruan dan IImu Pendidikan, Universitas Iqra Buru, Indonesia
}

"Korespondensi: rasyidrumatauniqbu@gmail.com

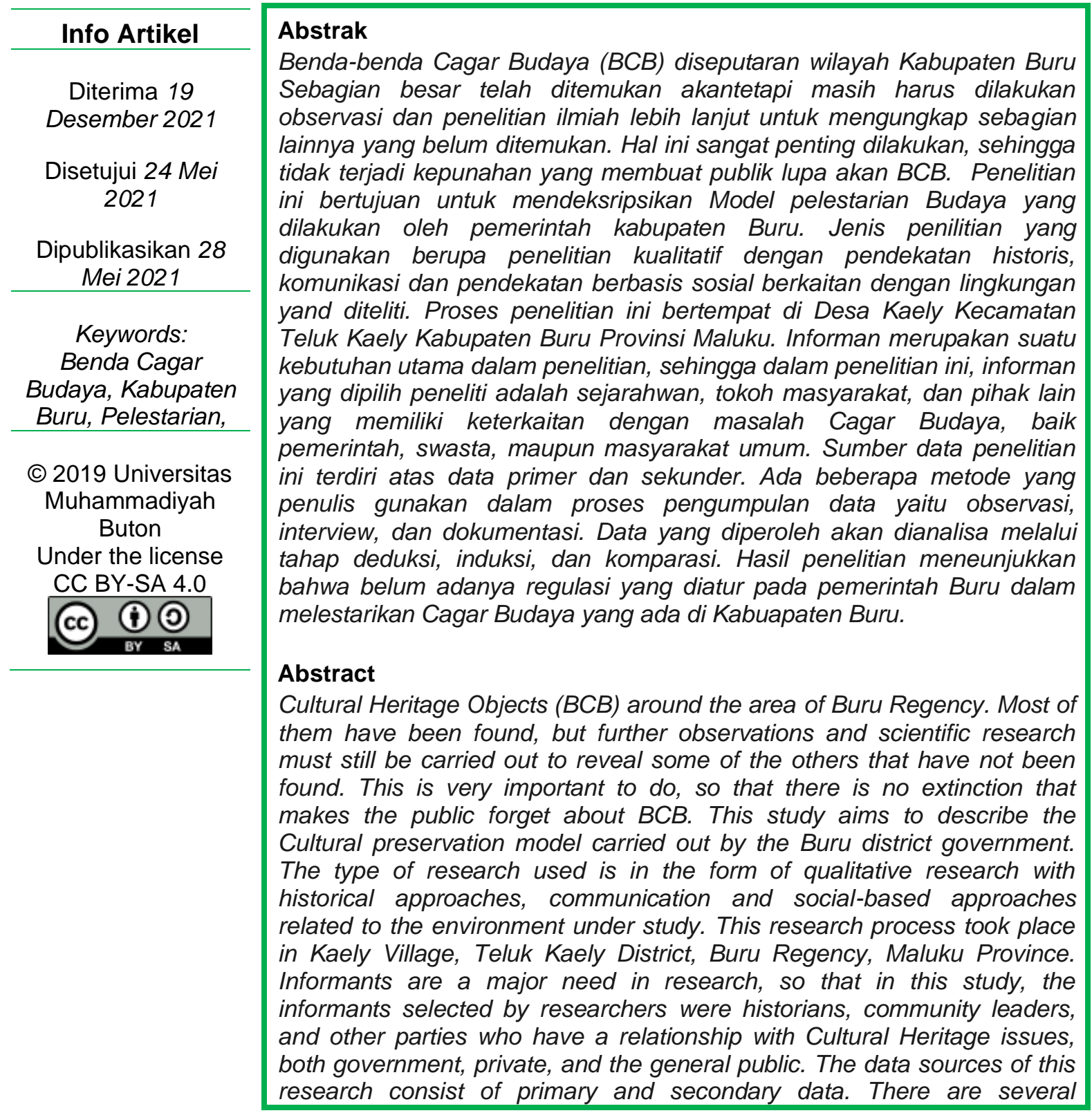


methods that the author uses in the data collection process, namely observation, interview, and documentation. The data obtained will be analyzed through the deduction, induction, and comparison stages. The results showed that there is no regulation that has been regulated by the Buru government in preserving the Cultural Heritage in Buru Regency.

\section{Pendahuluan}

Perjalanan sejarah bangsa secara totalitas, memiliki berbagai peristiwa masa lalu yang merupakan bagian dari legenda perjuangan yang tidak harus mengalami kelumpuhan seiring dengan regenerasi kehidupan bangsa itu sendiri. Dalam pamahaman tersebut, adanya berbagai keberadaan asset bangsa yang patut mendapat perhatian, sekaligus menjadi bagian dari sumber ilmu pengetahuan bagi generasi bangsa, senantiasa perlu diapresiasi dan ditumbuhkembangkan.

Kabupaten Buru dalam kawasan wilayah Provinsi Maluku, tentu memiliki keunikan tertentu, baik dalam bentuk pemetaan wilayah, kondisi sosiologis, maupun secara spesifik eksistensi budaya yang dimilikinya. Dalam kategori Arkeologi, Benda Cagar Budaya (BCB) maupun Kawasan Cagar Budaya (KCB), menjadi suatu kewajiban mutlak bagi daerah untuk melakukan perlindungan hukum terhadapanya, sebab BCB maupun KCB merupakan bagian integral dari kekayaan kearifan lokal yang secara nasional menjadi kekayaan budaya bangsa. Perlindungan BCB maupun KCB menjadi suatu keharusan untuk menjadi historis yang penghargaannya diteruskan oleh generasi bangsa. Dalam hal perlindungan tersebut patut dilakukan, baik BCB yang tidak bergerak maupun BCB yang bergerak. Demikian pula KCB, bahwa pada kawasan tertentu pasti terdapat penonjolan budaya yang menjadi ciri khas daerah, sehingga secara faer ikut mendapat perlindungan dan pengembangan serta kondusifitasnya dalam ketahanan memelihara tingkat budaya yang dilakoni (Kasiyanto, 1991).

Benda-benda Cagar Budaya diseputaran wilayah Kabupaten Buru, dalam sebagian besarnya telah terdeteksi, walaupun harus dilakukan observasi dan penelitian ilmiah lebih lanjut untuk mengungkap Sebagian lainnya yang masih harus dan terus dilakukan pencarian secara mendetail. Hal ini sangat penting dilakukan, sehingga tidak terjadi kepunahan yang membuat publik lupa akan BCB, bahkan tidak menghargai fenomena positif dari eksisitensi budayanya sendiri. Begitu pula kawasan tertentu, baik pada wilayah pedesaan maupun dusun atau perkampungan warga yang masih melekat dengan visual budaya yang berorientasi pada kearifan lokal, secara wajar harus mendapat apresiasi dalam perlindungan hukum oleh daerah. Tidak terkecuali adalah bahasa daerah, patut mendapat perhatian besar, dipandang perlu untuk dijadikan muatan lokal dalam pendidikan formal, sebab bahasa daerah merupakan hal pasti dalam pengenalan identitas suatu daerah setempat. Tidak semua kawasan dalam wilayah Kabupaten Buru menggunakan bahasa daerah "Bahasa Buru", namun dalam pertimbangan kebudayaan berdasarkan Undang-Undang No: 5 Tahun 1992 tentang Benda Cagar Budaya, maka pemaknaannya terhadap Kawasan Cagar Budaya tidak mengalami pengurangan nilai dalam perihal perlindungannya oleh daerah. 
Urgensi perlindungan terhadap $\mathrm{BCB}$ yang terakumulasi di dalamnya KCB menjadi suatu keharusan, sehingga pemeliharaan dan penghargaan terhadap kebudayaan daerah senantiasa mengalami dinamisasi, bahkan menjadi ruang pengkajian ilmu pengetahuan secara historis maupun sosiologis dan secara pasti menjadi bagian tidak terpisah dalam lahan pariwisata daerah. Oleh karena urgensi sebagaimana terkemukakan tersebut, maka dalam hal perlindungan hukum terhadap eksistensi asset daerah ini, sudah saatnya dilakukan sehingga jati diri daerah dalam masalah budaya menjadi lebih tertib dan kondusif tentunya (Jahi, 1993).

Cagar Budaya dalam istilah ilmiahnya adalah arkeologi, menjadi sesuatu yang urgen karena keberadaaanya bersentuhan langsung dengan eksistensi suatu komunitas masyarakat dan menjadi aikon budaya suatu daerah. Secara khusus, setidaknya sorotan gambaran umum terhadap eksistensi Cagar Budaya Pulau Buru, patut mendapat perhatian serius.

\section{Metode}

\subsection{Jenis dan Pendekatan Penelitian}

Jenis penilitian yang digunakan penulis yaitu penelitian kualitatif. Penelitian kualitatif adalah sebuah prosedur penelitian yang menghasilkan data deskriptif berupa kata-kata tertulis atau tersirat dari nara sumber dan objek yang dapat diamati sehingga dapat disebut sebagai penelitian berjenis deskriptif kualitatif (Sugiono, 2010).

Untuk mendapatkan data yang valid dari penelitian kualitatif ini, maka penulis melakukan komunikasi secara terbuka dengan narasumber atau mengamati objek penelitian, sehingga data yang diperoleh benar-benar akurat dan terpercaya. Dalam penelitian kualitatif sangat memerlukan ketajaman analisis, objektifitas dan sistematik sehingga diperoleh ketepatan dalam interpretasi pada subtansi masalah. Sedangkan pendekatan yang diambil dalam penelitian ini adalah pendekatan historis, komunikasi dan pendekatan berbasis sosial berkaitan dengan lingkungan yand diteliti.

Proses penelitian ini bertempat di Desa Kaely Kecamatan Teluk Kaely Kabupaten Buru Provinsi Maluku. Dipilihnya Desa Kaely sebagai lokasi penelitian, sebab pada desa tersebut merupakan daerah pertama kali adanya aktivitas sebelum hadirnya Kecamatan Namlea sebelum Pulau Buru dimekarkan menjadi daerah otonom kabupaten. Sisi lain, adanya peradaban yang terbangun di Desa Kaely ditandai dengan benteng peninggalan bangsa Portugis pada masa penjajahan.

Informan merupakan suatu kebutuhan utama dalam penelitian, sehingga dalam penelitian ini, informan yang dipilih peneliti adalah sejarahwan, tokoh masyarakat, dan pihak lain yang memiliki keterkaitan dengan masalah Cagar Budaya, baik pemerintah, swasta, maupun masyarakat umum.

\subsection{Jenis dan Sumber Data}

a. Jenis Penilitian

Proses penelitian ilmiah yang dilakukan oleh peneliti ini menggunakan jenis penelitian kualitatif. Penelitian kualitatif adalah sebuah prosedur penelitian yang 
menghasilkan data deskriptif berupa data tertulis atau lisan dari narasumber dan objek yang diamati (Sudjana, 1981).

b. Sumber Data

Pada penelitian ini terdapat dua jenis data yang digunakan yakni data primer dan data sekunder. Adapun data primer yaitu data yang diperoleh langsung peneliti dari informan pada lokasi penelitian. Data tersebut diperoleh dari hasil wawancara langsung dengan informan. Hal ini sesuai dengan pendapat Nawawi \& Martini (1996) yakni perkembangan model pelestarian budaya oleh masyarakat di Desa Kaely pada wilayah Kecamatan Teluk Kaely. Tentunya pada desa dan dusun tertentu yang berjarak dekat dengan Desa Kaely, ikut menjadi perhatian peneliti dalam menunjang perbendaharaan isi penelitian yang terfokus pada kepentingan pelestarian budaya di Kabupaten Buru. Sedangkan data sekunder adalah data tambahan yang digunakan sebagai penunjang, yakni data yang bersumber dari literatur tentang budaya, sosiologi, komunikasi, dan referensi lain yang relevan dengan masalah yang diteliti.

Data merupakan hal yang penting dalam suatu penelitian. Oleh karena itu, untuk memperoleh data diperlukan beberapa sumber yaitu: Adapun data yang digunakan dalam penelitian ini adalah :

1) Data primer yaitu data yang diperoleh dari penelitian dan pengamatan langsung terhadap objek di lapangan.

2) Data sekunder yaitu data yang diperoleh dari berbagai referensi baik dari buku maupun literatur lainnya.

\subsection{Metode dan Teknik Pengumpulan Data}

Metode pengumpulan data yang penulis gunakan yaitu melalui metode pendekatan historis, komunikasi dan pendekatan sosialogi. Ada beberapa metode yang penulis gunakan dalam proses pengumpulan data, di antaranya:

a. Observasi

Observasi yaitu pengamatan yang dilakukan dengan mengadakan pengamatan terhadap objek baik secara langsung maupun tidak langsung. Sehingga data dapat dihimpun dan disesuaikan dengan kebutuhan penelitian. Metode observasi ada dua macam yaitu observasi partisipan dan observasi non partisipan. Suatu observasi disebut partisipan, jika orang yang melakukan observasi mengambil bagian dalam kehidupan orang yang diobservasi. Dan jika tidak ada unsur partisipasi maka disebut non partisipan (Hadi, 2004).

Olehnya itu, untuk memperoleh data yang akurat dalam penelitian ini, maka penulis menggunakan observasi partisipan, dimana penulis ikut aktif didalam pengamatan secara langsung.

b. Interview/Wawancara

Inteview/Wawancara adalah metode pengumpulandata dengan jalan tanya jawab sepihak yang dikerjakan dengan sistematik dan berlandaskan kepada tujuan penyelidikan (Hadi, 2004).

Metode Interview/Wawancara ini ada dua macam yaitu interview terpimpin dan interview tak terpimpin. Interview tak terpimpin adalah tidak adanya kesengajaan pada pihak interview untuk mengarahkan tanya jawab ke pokok- 
pokok persoalan yang menjadi titik fokus dari kegiatan penyelidikan. Sedangkan interview terpimpin adalah penginterview terkait oleh suatu fungsi bukan saja sebagai pengumpul data melalui tanya jawab, melainkan sebagai pengumpul data yang relevan terhadap maksud-maksud penyelidikan yang sebenarnya dijalankan.

Dalam penelitian ini penulis menggunakan wawancara/interview bebas terpimpin untuk memperoleh data mengenai kondisi masyarakat Kaely, mengenai gambaran umum dan keadaan cagar budaya.

\section{c. Dokumentasi}

Metode pengumpulan data ini juga dikenal dengan penelitian dokumentasi (documentation research) yang mencari data melalui beberapa arsip dan dokumen yang berkaitan secara tertulis maupun dalam bentuk visual tertentu, berupa buku dan benda-benda tertulis lainnya yang relevan dengan substansi penelitian, (Suharsimi, 2002).

Metode ini penulis gunakan dalam hal yang dianggap penting yang ada hubungannya dengan data yang akan penulis selidiki.

\subsection{Teknik Analisis Data}

Analisis data dalam penelitian ini dilakukan dengan cara menata secara sistematik catatan hasil pengamatan data tertulis dan data tidak tertulis serta memprediksi hasil wawancara sebagai data pendukung, kemudian data yang sudah terkumpul diidentifikasi dan diklasifikasi dalam bentuk uraian. Selanjutnya dideskripsikan sebagai temuan dalam bentuk laporan penelitian.

Data yang diperoleh akan dianalisa dengan menggunakan metode sebagai berikut:

a. Deduksi yaitu metode analisis data yang bertitik tolak dari pengetahuan dan fakta-fakta yang bersifat umum kemudian mengambil kesimpulan yang bersifat khusus.

b. Induksi adalah metode analisis yang bertitik tolak dari pengetahuan dan faktafakta yang bersifat khusus kemudian mengambil kesimpulan yang bersifat umum.

c. Komparasi adalah metode analisis yang mencoba membandingkan dua data kemudian mencoba mengambil kesimpulan sendiri.

Ketiga teknik diatas digunakan untuk menganalisis data misalnya referensi dan sumber inspirasi penelitian pada umumnya.

\section{Pembahasan}

Dalam data penelitian ini yang menjadi obejek kajianya adalah model pelestarian cagar budaya di Desa Kaely Kecamatan Teluk Kaely Kabupaten Buru antara lain:

\subsection{Deskripsi Cagar Budaya (BCB)}

Menurut H. Gunadi Kasnowihardjo, penelitian pada Balai Arkeologi Yogyakarta, dalam buku Manajemen Sumber Daya Arkeologi, mengemukakan; sumber daya arkeologi merupakan bagian dari Benda Cagar Budaya maupun Kawasan Cagar Budaya. Dalam Undang-Undang Nomor: 5 Tahun 1992 tentang $\mathrm{BCB}$, Situs, dan KCB. 
Penelitian terdahulu oleh Fitri Nuraini pada tahun 2013, mengangkat judul Pelestarian Nilai Budaya Dalam Seni Tari Tarwangsa di Kabupaten Sumedang (Suatu Studi Pada Sekolah Sebagai Pusat Budaya). Penelitian ini dilakukan pada SMA Negeri Rancakalong yang menerapkan tari tarawangsa sebagai bagian dari pembelajaran dalam kurikulum yang sekolah dimaksud sebagai bagian integral dari pengembangan tradisi pada daerah setempat dalam pelestarian kearifan lokal berbasis budaya.

Dessi Ulandari dalam penelitian berjudul Penerapan Nilai-Nilai Kearifan Lokal Dalam Kehidupan Masyarakat di Era Globalisasi (Suatu Penelitian di Desa Lampaseh Krueng Kecamatan Montasik Aceh Barat). Penelitian ini berorientasi pada deskripsi penerapan kearifan lokal tentang adat Peusijuk pada masyarakat Lampaseh Krueng Kecamatan Montasik di era globalisasi, guna mengetahui kendala apa saja yang terjadi dalam proses penerapan adat Peusijuk untuk pengembangannya dari generasi ke generasi. Sehingga diharapkan budaya lokal tidak hilang dan menjadi kekayaan bangsa yang merupakan warisan dari orangorang terdahulu yang patut dijaga dan dilestarikan dalam kehidupan masyarakat Aceh.

Dengan demikian penelitian tersebut berorientasi yang sama tentang budaya, namun berbeda konteks maupun tempat dengan penelitian yang dilakukan oleh peneliti pengusul sekarang ini. Dalam penelitian ini, peneliti menaruh fokus terhadap pelestarian cagar budaya yang senantiasa terjaga dengan baik serta adanya perhatian dalam perawatannya. Dengan demikian diharapkan pelestarian budaya berupa cagar budaya dan tradisi yang melekat pada masyarakat menjadi bagian dari pengembangan ilmu pengetahuan di bidang pendidikan dan sosial budaya dari perjalanan historis oleh masyarakat Kabupaten Buru pada Desa Kaely terdahulu, sehingga menjadi pelajaran berharga bagi generasi sekarang dan generasi yang akan datang, sekaligus merupakan asset kekayaan budaya bangsa yang berkembang dari Desa Kaely Kecamatan Teluk Kaely Kabupaten Buru Provinsi Maluku.

Undang-undang No.11 tahun 2010 tentang cagar budaya; Pasal 1 yang menyatakan "Cagar Budaya adalah warisan budaya bersifat kebendaan berupa Benda Cagar Budaya, Bangunan Cagar Budaya, Struktur Cagar Budaya, Situs Cagar Budaya, dan Kawasan Cagar Budaya di darat dan/atau di air yang perlu dilestarikan keberadaannya karena memiliki nilai penting bagi sejarah, ilmu pengetahuan, pendidikan, agama, dan/atau kebudayaan melalui proses penetapan. Bangunan Cagar Budaya adalah susunan binaan yang terbuat dari benda alam atau benda buatan manusia untuk memenuhi kebutuhan ruang berdinding dan/atau tidak berdinding, dan beratap."

Undang-undang No.11 tahun 2010 tentang cagar budaya; Pasal 5 yang menyatakan "Benda, bangunan, atau struktur dapat diusulkan sebagai Benda Cagar Budaya, Bangunan Cagar Budaya, atau Struktur Cagar Budaya apabila memenuhi kriteria:

a. Berusia 50 (lima puluh) tahun atau lebih;

b. Mewakili masa gaya paling singkat berusia 50 (lima puluh) tahun;

c. Memiliki arti khusus bagi sejarah, ilmu pengetahuan, pendidikan, agama,

d. dan/atau kebudayaan; dan 
e. Memiliki nilai budaya bagi penguatan kepribadian bangsa."

Undang-undang No.11 tahun 2010 tentang cagar budaya; Pasal 77 yang menyatakan:

a. Pemugaran, Bangunan Cagar Budaya dan Struktur Cagar Budaya yang rusak dilakukan untuk mengembalikan kondisi fisik dengan cara memperbaiki, memperkuat, dan/atau mengawetkannya melalui pekerjaan rekonstruksi, konsolidasi, rehabilitasi, dan restorasi.

b. Pemugaran, Cagar Budaya sebagaimana dimaksud pada ayat (1) harus memperhatikan:

1)Keaslian bahan, bentuk, tata letak, gaya, dan/atau teknologi pengerjaan

2)Kondisi semula dengan tingkat perubahan sekecil mungkin

3)Penggunaan teknik, metode, dan bahan yang tidak bersifat merusak

4)Kompetensi pelaksana di bidang pemugaran.

Peraturan Menteri No. 01/PRT/M/ 2015 tentang gedung cagar budaya yang dilestarikan; Pasal 7 yang menyatakan:

a. Persyaratan tata bangunan sebagaimana dimaksud dalam pasal 6 terdiri atas:

1) Peruntukan dan Intensitas bangunan Gedung, 2) Arsitektur bangunan Gedung dan 3) Pengendalian dampak lingkungan

b. Persyaratan tata bangunan sebagaimana dimaksud pada ayat (1) hanya diberlakukan dalam hal bangunan gedung cagar budaya yang dilestarikan mengalami perubahan fungsi, bentukm karakter fisik dana tau penambahan gedung.

Peraturan Menteri No. 01/ PRT/M / 2015 tentang gedung cagar budaya yang dilestarikan: Pasal 14 yang menyatakan:

1. Rekomendasi dan tindakan pelestarian bangunan gedung cagar budaya sebagaimana dimaksud dalam pasal 12 ayat (5) berupa: - perlindungan . pengembangan, dan pemanfaatan.

2. Perlindungan sebagaimana dimaksud pada ayat (1) huruf a terdiri atas: a) Pemeliharaan dan b) Pemugaran

3. Pengembangan sebagaimana dimaksud pada ayat (1) huruf $b$ terdiri atas: a) Revitalisasi dan b) Adaptasi

Peraturan Menteri No. 01/PRT/M/ 2015 tentang gedung cagar budaya yang dilestarikan; Pasal 16 yang menyatakan "Adaptasi sebagaimana yang dimaksud dalam pasal 14 ayat (3) huruf b dilakukan melalui upaya pengembangan bangunan gedung cagar budaya untuk kegiatan yang lebih sesuai dengan kebutuhan masa kini dengan cara melakukan perubahan terbatas yang tidak mengakibatkan penurunan nilai penting atau kerusakan pada bagian yang mempunyai nilai penting."

Menurut H. Gunadi Kasnowihardjo, penelitian pada Balai Arkeologi Yogyakarta, dalam buku Manajemen Sumber Daya Arkeologi, mengemukakan; sumber daya arkeologi merupakan bagian dari Benda Cagar Budaya maupun 
Kawasan Cagar Budaya. Dalam Undang-Undang Nomor: 5 Tahun 1992 tentang $\mathrm{BCB}$, Situs, dan KCB.

\subsection{Eksistensi Benda Cagar Budaya}

Identitas atau ikon suatu daerah maupun sebuah bangsa, tidak terlepas dari cagar budaya yang dimiliki (Muhammad, 2011). Yang dimaksud dengan Benda Cagar Budaya adalah:

1. Benda buatan manusia, bergerak maupun tidak bergerak yang berupa kesatuan atau kelompok, atau bagian-bagiannya, atau sisa-sisanya. Yang berumur sekurang-kurangnya 50 (lima puluh) tahun, serta dianggap mempunyai nilai penting bagi sejarah, ilmu pengetahuan, dan kebudayaan.

2. Benda alam yang dianggap mempunyai nilai penting bagi sejarah, ilmu pengetahuan, dan kebudayaan.

Sedangkan Situs dalam Undang-Undang di atas berorientasi pada keadaan lokasi yang mengandung atau diduga mengandung benda cagar budaya, termasuk lingkungannya yang diperlukan bagi bagi pengamannnya.

\subsection{Kepemilikan BCB/KCB}

Benda Cagar Budaya ataupun Kawasan Cagar Budaya yang merupakan asset daerah, diakui merupakan kepemilikan yang ada pada historis individu maupun kelompok suatu masyarakat secara turun-temurun atau diperoleh secara sengaja (penemuan), baik berupa benda bergerak maupun tidak bergerak. Namun dalam normalisasinya, maka pemberlakukan perlindungan harus diletakkan sebagai legalitas formal dalam pengakuan secara universal (Mubyanto, 2011).

\subsection{Urgensi Pelestarian Cagar Budaya Kabupaten Buru}

Benda Cagar Budaya Kabupaten Buru dipandang penting untuk dilestarikan sebagai pembentukan jati diri dalam hal identitas daerah, yang belum tentu Benda Cagar Budaya dimaksud dimiliki oleh daerah lain, bahkan wilayah lain secara nasional (Syaukani, 2020). Secara spesifik Benteng Brunyi peninggalan bangsa Portugis pada masa VOC pada tahun 1785 dan Desa Kaely yang merupakan Ibu Kota pertama di Pulau Buru. Pada tahun 1919 karena akibat banjir bandang yang meluap melalui sungai yang berdampingan dengan benteng bersejarah ini, oleh bangsa Belanda ibu kota dipindahkan ke Namlea yang menjadi pusat lbu Kota Kabupaten Buru hingga tahun 2020 bersamaan dengan penelitian ini dilakukan. Selain fokus penelitian pada hostoris benteng VOC sebagai cagar budaya yang dibangun pada tahun 1785 kepemimpinan Bernadus Van Pleuren diawal abad 19. Peneliti juga melakukan penelusuran pada Dusun Lokasi yang merupakan salah satu wilayah petuanan Desa Kaely yang hingga kini masih memberlakukan system pemerintahan kerajaan, disamping pemerintahan kecamatan dan desa dalam hokum positif sebagaimana umumnya, dimana marga Wael yang menduduki tahta dalam jabatan raja hingga sekarang.

Terdapat temuan yang yang menyimpang dari harapan pelestarian cagar budaya yang sebenarnya pada kondisi benteng bersejarah ini, yakni:

a) Kondisi fisik benteng peninggalan VOC di Desa Kaely Kecamatan Kabupaten Buru tidak terawatt sebagaimana harusnya.

b) Totalitas dinding benteng dipenuhi lumut dan tumbuhan rumput semak. 
c) Tinggi bangunan benteng sebagaimana pembangunan awal sejarahnya, memiliki ukuran tinggi 6 meter rata-rata untuk pintu masuk ruang dalam benteng dari permukaan tanah, dan pada gerbang penjagaan di empat sudut berukuran tinggi mencapai 9 meter. Hingga penelitian ini dilakukan di tahun 2020, kondisi benteng ini seolah fisiknya ditelan bumi, dengan ukuran sejajar dari pintu masuk ruang benteng hanya mencapai 1,47 meter. Sedangkan area bagian dalam ruang benteng ditumbuhi rerumputan yang lebat dan dijadikan perkebunan tanaman pohon papaya, terong, tomat, pohon mangga dan lainlain.

Cagar budaya merupakan hal menarik sehingga Benda Cagar Budaya Kabupaten Buru perlu dilestarikan karena:

1. Benda Cagar Budaya termasuk dalam sesuatu fenomena yang langka dan tidak terbarukan (unrenewble), artinya bahwa Benda Cagar Budaya maupun Kawasan Cagar Budaya yang dimiliki oleh daerah tidak dapat ditukar dengan benda lain, sekalipun sejenis.

2. Benda Cagar Budaya memiliki kategori sebagai hal yang unik, dengan memiliki nilai-nilai historis, arsitektur, maupun ekologi yang khas sehingga menjadi daya tarik untuk dikunjungi para wisatawan, yang pada gilirannya memberikan keuntungan bagi wilayah Kabupaten Buru secara khusus.

Selanjutnya dalam cara perlindungan terhadapnya, dapat diarahkan dalam perlindungan berbentuk hukum dan perlindungan secara fisik (Hadrawi Nawawi, n.d.). Sedangkan pemanfaatan yang kemukakan dalam literatur ilmiah tentang Benda Cagar Budaya adalah sebagai berikut:

a) Scientific research; artinya bahwa Benda Cagar Budaya adalah sebagai pengembang ilmu dalam berbagai disiplin ilmu pengetahuan.

b) Creative Arts; artinya Benda Cagar Budaya dapat menjadi sumber inspirasi bagi seniman, sastrawan, penulis atau peneliti, akademisi, dan fotografer.

c) Education; artinya Benda Cagar Budaya adalah bagian dari lahan garapan dalam pengembangan nilai pendidikan.

d) Recreation and Tourism; artinya Benda Cagar Budaya pada prinsipnya menjadi objek wisata dan budaya.

e) Symbolic representation; artinya Benda Cagar Budaya merupakan symbol kehidupan manusia dalam suatu keberdaan masyarakat.

f) Legitimation of Action; artinya Benda Cagar Budaya dalam historis keberadaannya tidak terlepas dari kepemilikan, baik individu, suatu kelompok, maupun intistusi tertentu.

g) Social Olidarity and Integration; artinya Benda Cagar Budaya menjadi wahana dalam memotivasi solidaritas social dan integrasi yang kuat dalam suatu masyarakat.

Monetary and Economi Gain; artinya Benda Cagar Budaya sebagaimana umumnya, tentu menjadi objek wisata budaya, sehingga mendatangkan keuntungan bagi masyarakat disekitar objek Benda Cagar Budaya tersebut (Marbun, 1983) . 


\subsection{Pelestarian Cagar Budaya Menurut Masyarakat Desa Kaely}

Data lapangan yang diambil dalam penelitian ini melalui observasi, wawancara, dan pengisian kuisioner dengan keberadaan peneliti sebagai instrument utama yang secara langsung berada dilapangan dan bersentuhan langsung dengan warga masyarakat sebagai responden pada Juli 2020. Adapun proses pelestarian cagar budaya yang terfokus pada benteng VOC menurut masyarakat.

\section{a. Menurut Umar Taramun}

Dikemukakan bahwa pada tahun 1657 datang penjajah bangsa Portugis bernama Simondecus yang mula-mula memulai pembuatan benteng yang terbuat dari kayu kemudian dirubah dengan struktur pembangunan benteng tersebut dari kumpulan susunan batu. Umar Taramun yang berkapasitas sebagai Kepala Desa Kaely ini menuturkan sebagaimana sejarahnya, maka pada tahun 1689 VOC mulai masuk menempati Desa Kaely, hingga tahun 1785 disusul oleh bangsa Belanda yang ikut menduduki Desa Kaely sebagai pusat pemerintahan petuanan kerajaan, bahkan Desa Kaely merupakan kota pertama dan desa tertua di Kabupaten Buru, dan pada tahun 1910 kemudian ibu kota pemerintahan negeri Kaely dipindahkan ke Namlea yang ditandai dengan pemindahan tiang bendera pemerintahan.

Kondisi benteng yang menjadi cagar budaya di daerah Kabupaten Buru Provinsi Maluku, tepatnya di Desa Kaely Kecamatan Teluk Kaely, hingga bertepatan dengan penelitian ini, proses perawatan sebagai bentuk pelestariannya menjadi swadaya masyarakat yang banyak keterbatasan, sehingga nampak fisik bangunan benteng serta lingkungan sekitar area benteng diakui tidak terurus.

\section{b. Menurut Abdullah Surnia}

Kondisi benteng bersejarah yang pada zaman penjajahan Belanda disebut benteng Defencie di Desa Kaely, sangat jauh dari perhatian Pemerintah Daerah Kabupaten Buru maupun Pemerintah Provinsi Maluku. Oleh karena itu diakui sangat wajar apabila benteng yang menjadi bagian dari tanda perjalanan sejarah bangsa di daerah ini, kondisinya sangat memprihatinkan sebagaimana dilihat dengan mata telanjang.

Sebagai tokoh masyarakat Desa Kaely, Abdullah Surnia sangat prihatin dan menyayangkan ketidakpedulian berbagai pihak sebagai pemangku kebijakan dan kepentingan di daerah, maupun pemerintah pusat yang terkesan melakukan pembiaran terhadap pelestarian cagar budaya yang tidak optimal seperti tidak terawatnya benteng VOC di desa ini.

\section{c. Menurut Ibrahim Wael}

Dalam kapasitas sebagai tokoh adat negeri Desa Kaely, Ibrahim Wael mengemukakan keprihatinan yang sama sebagaimana responden lainnya. Menurutnya, sebagai bangsa yang besar, mestinya menghargai sejarah bangsanya sendiri, salah satu dari bentuk penghargaan tersebut adalah secara terus-menerus dilakukannya pelestarian cagar budaya sebagaimana yang luar biasa dilakukan oleh daerah lain, baik dalam lingkup local Maluku, secara nasional bangsa, maupun cagar budaya dunia pada Negara-negara tertentu.

Ibrahim Wael menegaskan kepada pemerintah agar pelestarian cagar budaya di Desa Kaely menjadi wajib untuk mendapat perhatian serius dalam 
perawatannya sebagai wujud penghargaan terhadap sejarah bangsa. Setidaknya pelestarian cagar budaya benteng peninggalan VOC bangsa Portugis yang kemudian dilanjutkan oleh bangsa Belanda mendudukuinya ini, pada akhirnya berdampak baik terhadap potensi pariwisata lokal. Responden ini berharap adanya penelitian yang berkelanjutan untuk dapat mengungkap sejarah lainnya yang berhubungan dengan harapan pelestarian cagar budaya, antara lain:

a. Penelitian keberadaan masjid tua di Desa Kaely

b. Penelitian keberadaan gereja tua di Desa Kaely

c. Penelitian keberadaan istilah Kerko

d. Penelitian tentang kearifan lokal tarian cakalele

e. Penelitian tentang budaya peringatan 1 Muharam

f. Penelitian tentang tradisi tarian penggunaan kain lestari adat Buru

g. Penelitian tentang kearifan lokal tarian Sawat Buru

\section{Penutup}

Dari hasil pembahasan masalah penelitian tersebut, dapat disimpulkan bahwa Model pelestarian cagar budaya merupakan hal wajib yang diharuskan oleh Negara. Bahwa benteng peninggalan VOC di Desa Kaely Kecamatan Teluk Kaely Kabupaten Buru Provinsi Maluku yang secara fisik mengalami keterpurukan akibat tidak mendapat perhatian perawatan, sehingga dibutuhkan pengendalian oleh pemerintah daerah dan kesadaran masyarakat setempat yang hidupnya lebih dekat dengan posisi benteng tersebut, perlu meningkatkan animo dalam rangka pelestarian benteng Brunyi oleh VOC kemudian berubah nama menjadi benteng Defencie pada fase penjajahan Belanda sebagai salah satu asset bangsa yang terdapat di daerah bertajuk Bupolo penghasil minyak kayu putih ini.

Sekiranya dalam proses pelestarian cagar budaya, benteng kaely kembali dilakukan perawatan yang optimal untuk mengembalikan bentuk sisi fisik bangunan dengan cara rehabilitasi dan pembersihan bangunan, dan lingkungan sekitar benteng mendapat pengamanan berupa tembok atau pagar pembatas, bersih, dan terdapat penjagaan dari orang tertentu yang dipekerjakan sebagai security atau pemandu benteng, dengan adanya campur tangan pemerintah dalam pelestariannya. Bahkan benteng tersebut dapat dimanfaat sebagai media untuk meningkatkan potensi pariwisata di Kabupaten Buru.

\section{Daftar Pustaka}

Hadi, S. (2004). Metodologi research jilid I. Yogyakarta: Andi. https://doi.org/10.1038/emboj.2012.81

Jahi, A. (1993). Komunikasi Massa dan Pembangunan Pedesaan di NegaraNegara di Dunia Ketiga: Suatu Pengantar. PT. Gramedia Pustaka Utama.

Kasiyanto, M. . (1991). Masalah dan Strategi Pembangunan Indonesia. PT. Pustaka Pembangunan Swadaya Nusantara.

Marbun, B. N. (1983). DPR Daerah Pertumbuhan Masalah dan Masa Depannya (1st ed.). Ghalia Indonesia.

Mubyanto. (2011). Prospek Otonomi Daerah dan Perekonomian Indonesia Pasca 
Krisis Ekonomi (1st ed.). BPFE-Yoyakarta.

Muhammad, A. (2011). Membaca Karakter Orang Berdasarkan Etnisnya (1st ed.). Najah.

Nawawi, Hadari, \& Martini, M. (1996). Penelitian Terapan. Gaja Mada University Press.

Nawawi, Hadrawi. (n.d.). Metode Penelitian Bidang Sosial. (8th ed.). Gajah Mada University Press.

Sudjana, N. (1981). Penelitian dan Penilaian Pendidikan. Sinar Biru.

Sugiono. (2010). Metode Penelitian Administrasi. (2nd ed.). Alfabeta.

Suharsimi, A. (2002). Prosedur Penelitian; Suatu Pendekatan Praktek. Rineka Cipta.

Susiati, S. (2020). Nilai Budaya Suku Bajo Sampela Dalam Film The Mirror Never Lies Karya Kamila Andini.

Syaukani, H. (2020). Titik Temu dalam Dunia Pendidikan Tanggung Jawab Pemerintah, Pendidik, Masyarakat, dan Keluarga Dalam Membangun bangsa (1 (ed.)). Nunusa Madani. 